\title{
General considerations for linkedin of an electric technology buses in the transport systems - test results of an fully electric articulated bus (18 meters) from Bogotá to Pereira city, Colombia.
}

\author{
DOI: $10.46932 / \mathrm{sfjdv2n2-007}$
}

Received in: January 1st, 2020

Accepted in: March 30th, 2020

\section{Diego Armando Vargas R.}

Production Engineer. Engineering Project Management Specialist. Master in Environmental Management. Master in Process Engineering. PhD student in Engineering at the University of Cádiz. Professional experience superior to 8 years in maintenance management in BRT systems. 3 year in electric vehicle and more than 4 years of experience as a university education teacher.

E-mail: ingprodvargas@gmail.com

\section{Cristina Vanessa Durán G}

$\mathrm{PhD}$ Industrial engineering. Department of Thermal Engines and Machines, School of Marine, Nautical and Radioelectronic Engineering, Campus of International Excellence of the Sea (CEIMAR), University of Cadiz, Spain.

E-mail: Vanesa.duran@uca.es

\begin{abstract}
The introduction to new technologies in the different land of transportation system represents a great opportunity for the academy, opening up space for applied research that evaluates from different angles, factors that are part of the processes and consequences that implicitly may come hand in hand with these. With this study a review of general aspects linked to operation of a fully electric articulated bus in the travel from Bogotá to Pereira, Colombia

This travel was started on early morning October 13,2019, since the start point it has been monitoring the energy consumption for that make up the OPEX (Operational expenditures), in order to give a concept that is valid input information in the technical and economic evaluation process for change the buses in transport intercity systems, as a comparison is built with previous scientifically proven records for other diesel and hybrid articulated bus technologies.
\end{abstract}

Keywords: BRT, OPEX, CAPEX, e-mobility, Articulated, Electric Vehicle (EV), SOC (State of charge)

\section{INTRODUCTION}

Worldwide, the big cities, face a challenge in relation to air quality where traffic is a key element. Air pollution is the origin of a large number of deaths per year. The energy dedicated to transport exceeds $33 \%$ of all used energy and $40 \%$ of the emissions. In large urban centres, $66 \%$ of NOx contamination, the most severe for people's health, is produced by road traffic. Buses on regular urban lines generate only $7.5 \%$ of this percentage ${ }^{1}$, Public transport is therefore essential to achieve the objectives of air quality.

\footnotetext{
${ }^{1}$ Reina G., Paiano M., and Blanco J.: Vehicle parameter estimation using a model-based estimator. Mechanical Systems and Signal Processing. Vol. 87, Part B, 15 March 2017, Pages 227-241. https://doi.org/10.1016/j.ymssp.2016.06.038
} 
Despite of this, the high initial investment (CAPEX) of e-buses compared to hybrid diesel-electric and diesel technology, in addition with the uncertainty of the variables in the operation stage, regarding the useful life and buses maintenance, it represents a difficult for the the implementation and massification of e-mobility. ${ }^{2}$.

This investigation gathers information from the technical study of the operation variables of a fully electric articulated bus in the travel from Bogotá to Pereira, Colombia.

\section{GENERAL OBJECTIVE:}

Consolidate a review of the operating test results of an articulated fully electric bus on travel from Bogotá to Pereira city, Colombia.

\section{SPECIFIC OBJECTIVES:}

1. Present the general results of the operation test of an articulated fully electric bus from Bogotá to Pereira.

2. Performing a conceptual consolidation of the energy consumption cost hat make up the OPEX of an fully electric articulated bus compared to a hybrid bus and a traditional diesel combustion bus.

\section{METHODOLOGY:}

The process cites the concepts of experimental practical research that seeks to analyze the operation results of an articulated fully electric bus in travel from Bogotá to Pereira city, in Colombia.

It also includes elements of the field research carried out by the time and place of occurrence of the studied phenomenon. The research is framed in the experimental quantitative analysis.

The case of study and the applied research is proposed as the methodology "strategy aimed at understanding the dynamics present in unique contexts", which could lead to the study of operational experiences tests that are carried out in other transport systems and this way to review in context the general aspects of linking fully electrical technologies.

For this research, the quantitative analysis of the operation experience of a fully electric articulated bus in travel from Bogotá to Pereira city. The operation variables was analyzed as a field work looking for an approach as close as possible to the details of the experience:

- Route

2 La electromovilidad en el transporte público en América Latina. Depósito legal: DC2019000315 ISBN: 978-980-422-143-9 (2019). Pages 10-11. 
- $\quad$ Total $\mathrm{km}$ traveled

- Operation time

- $\quad$ Energy consumption

- Geographic characteristics

\section{RESULTS STUDY}

The route from Bogotá to Pereira city is part of an InterCitys roads Transportation System that walk the top of the line, that is a mountain route located in the Central Mountain range of the Andina Region, in the Salento municipality jurisdiction and connects Calarcá towns, in Quindío department, and Cajamarca, in Tolima department. Some route characteristics are detailed below in the Tables 1:

Table 1. Route characteristics

\begin{tabular}{lccccc}
\hline ROUTE & $\begin{array}{c}\text { DISTANCE } \\
(\mathbf{k m})\end{array}$ & $\begin{array}{c}\text { MAXIMUM } \\
\text { SLOPE }\end{array}$ & $\begin{array}{c}\text { MINIMUM } \\
\text { SLOPE }\end{array}$ & $\begin{array}{c}\text { MAXIMUM } \\
\text { ALTITUDE } \\
\text { (meters } \\
\text { above sea level) }\end{array}$ & $\begin{array}{c}\text { MINIMUM } \\
\text { ALTITUDE } \\
\text { (meters } \\
\text { above sea level) }\end{array}$ \\
\hline $\begin{array}{l}\text { Bogotá } \\
\text { to }\end{array}$ & 312 & $19 \%$ & $0 \%$ & 3266 & 285 \\
Pereira & & & & & \\
\hline
\end{tabular}

Source: made of authors

Some characteristics of the fully electric articulated bus are described below in the Table 2:

Table 2. fully electric bus Characteristics

\begin{tabular}{lc}
\hline \multicolumn{1}{c}{ DESCRIPCIÓN } & VALOR \\
\hline Brand & BYD \\
\hline Long & $18000[\mathrm{~mm}]$ \\
\hline Width & $2530[\mathrm{~mm}]$ \\
\hline Height & $3270[\mathrm{~mm}]$ \\
\hline Gross Weight (GVWR) & $30000[\mathrm{~kg}]$ \\
\hline Seats / Passengers & $60[\mathrm{~km} / \mathrm{h}]$ \\
\hline $\begin{array}{l}\text { Maximum speed } \\
\text { regulation }\end{array}$ & $19[\%]$ \\
\hline $\begin{array}{l}\text { Maximum climbing } \\
\text { capacity on a slope }\end{array}$ & $280[\mathrm{~mm}]$ \\
\hline Height to the ground & $>350[\mathrm{~km}] *$ \\
\hline Autonomy & Adjustable air suspension \\
\hline Suspension & $\mathrm{Wheelchair}$ area \\
\hline
\end{tabular}


Braking system

\begin{tabular}{lc}
\hline Tires & $295 / 80 \mathrm{R} 22.5$ \\
\hline Electric motors & AC permanent magnet motors \\
\hline Maximum power & $(180[\mathrm{~kW}]$ x 2) y (492) $[\mathrm{HP}]$ \\
\hline Maximum torque & $3000[\mathrm{Nm}] /(1500[\mathrm{Nm}] \mathrm{x} 2)$ \\
\hline Battery Type & Iron phosphate battery \\
\hline $\begin{array}{l}\text { Energy capacity } \\
\text { (nominal) }\end{array}$ & $450[\mathrm{Wh}] / 550[\mathrm{~V}]$ \\
\hline
\end{tabular}

* Relative reference value; it can vary depending on operating conditions

Source: KF1 Operator manual fully electric bus

The OPEX in buses operation in transport systems, are made up of several cost centers, among those with a higher proportion, energy consumption, that is transversal for all bus technologies.

For the case study, information was recorded since the start point, and it was completed in destining station; for which a total of 17 data was obtained for each of the two independent variables $(\mathrm{km}$ traveled and kWh energy consumption).

In the table 3 there is testing data summary:

Table 3. Test data summary

\begin{tabular}{cc}
\hline SOURCE & DATA \\
\hline ORIGIN & Bogotá - Portal Suba \\
\hline DESTINATION & Pereira - Cuba Station \\
\hline DISTANCE TRAVELED & $312 \mathrm{~km}$ \\
\hline START SOC & $100 \%$ \\
\hline ARRIVAL SOC & $56 \%$ \\
\hline OCCUPANCY & Source: made of authors
\end{tabular}

The energy consumption as a result of the relation between the total of $\mathrm{kWh}$ as a result of the relation between SOC and the total battery capacity $450 \mathrm{~kW}$ :

$$
\text { Total consumption } \mathrm{kWh}=450-(\mathrm{SOC} \times 450)
$$

kWh: Kilowatt hour

SOC: State of Charge 
In table 4 there are data details of the energy consumption during the route, also the energy efficiency as a result of the relation between the total of $\mathrm{kWh}$ and the $\mathrm{km}$ traveled. As a reference taken the calculation shows a cost of 0,16 USD ( $\$ 608 \mathrm{COP}$ ) per one $\mathrm{kWh}$ (exogenous variable taken from the commercial information of the supplier energy service company in Bogotá), the total cost of energy consumption is calculated, and finally the relationship between the total cost and the kilometers traveled, allows obtaining the cost per unit of $\mathrm{km}$.

$$
\text { CTO. } \mathrm{CE} / \mathrm{km}=\frac{\sum \mathrm{kWh}}{\sum \mathrm{km}} \times 0,16 \mathrm{USD}
$$

CTO. CE: Energy consumption cost

kWh: Kilowatt hour

km: Kilometers traveled

Table 4. Efficiencies and costs of energy consumption

\begin{tabular}{|c|c|c|c|}
\hline KM TRAVEL & SOC (\%) & $\begin{array}{c}\text { ENERGY } \\
\text { CONSUMPTION } \\
(\mathrm{kWh}) \\
\end{array}$ & $\begin{array}{c}\text { RELATIVE ENERGY } \\
\text { COST } \\
(0,16 \text { USD/ kWh }) \\
\end{array}$ \\
\hline 0 & 100 & 0 & USD 0,000 \\
\hline 27,3 & 93,3 & 30,15 & USD 0,177 \\
\hline 40 & 97,1 & 13,05 & USD 0,052 \\
\hline 89,9 & 100 & 0 & USD 0,000 \\
\hline 102,1 & 100 & 0 & USD 0,000 \\
\hline 117 & 97 & 13,5 & USD 0,018 \\
\hline 131,4 & 95,4 & 20,7 & USD 0,025 \\
\hline 145,2 & 94,3 & 25,65 & USD 0,028 \\
\hline 161 & 89,4 & 47,7 & USD 0,047 \\
\hline 172,6 & 85,2 & 66,6 & USD 0,062 \\
\hline 191 & 78,4 & 97,2 & USD 0,081 \\
\hline 209,3 & 70,2 & 134,1 & USD 0,103 \\
\hline 233 & 49,5 & 227,25 & USD 0,156 \\
\hline 254,4 & 30,4 & 313,2 & USD 0,197 \\
\hline 270 & 51 & 220,5 & USD 0,131 \\
\hline 294 & 44 & 252 & USD 0,137 \\
\hline 312 & 56 & 198 & USD 0,102 \\
\hline
\end{tabular}

In the image 1 there is data details of the SOC and $\mathrm{km}$ traveled in some different points during the route, and the red line in the graphic represents the altitude above sea level and geography during the route: 
Image 1. Altitude and data details of the SOC and $\mathrm{km}$

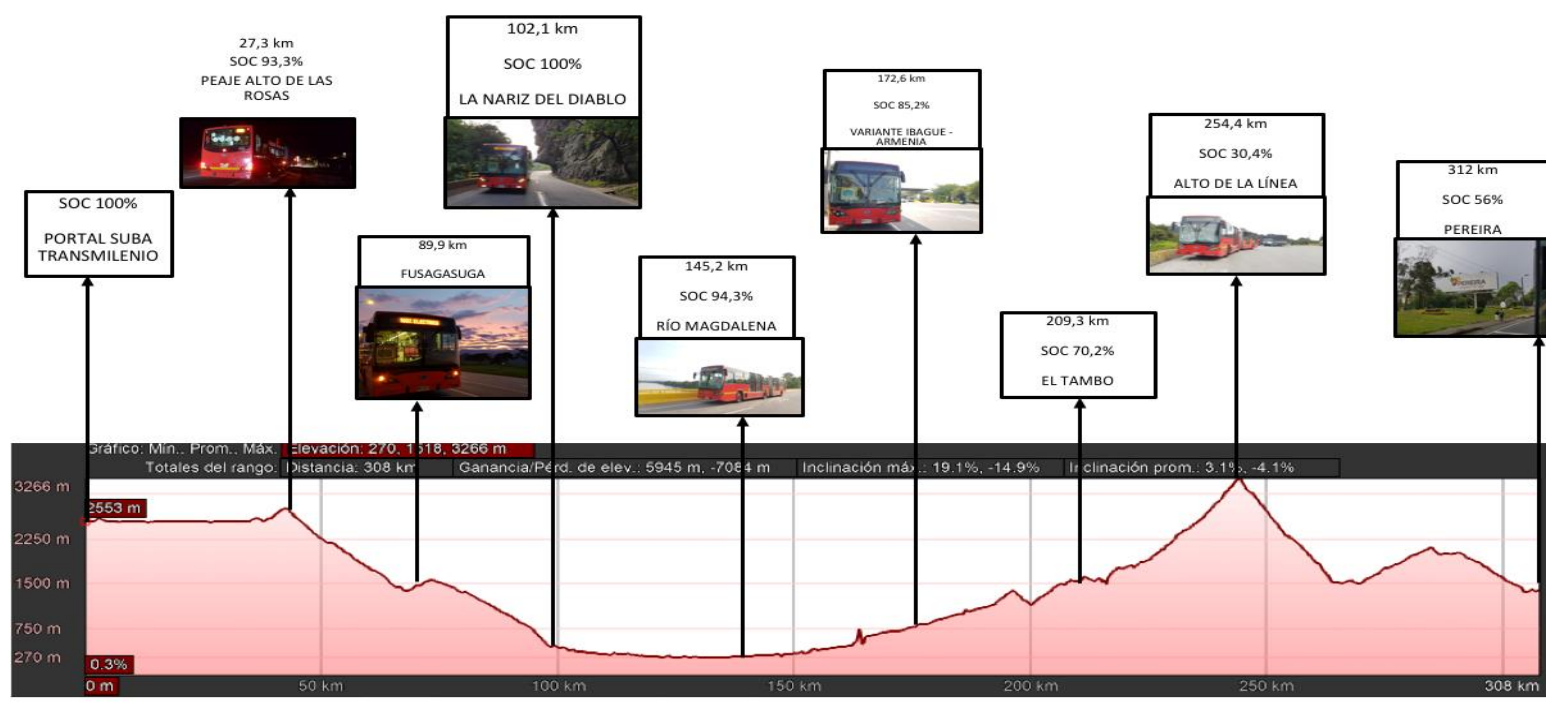

Source: made of authors

The fully electric articulated bus used in the test, has a property that allows to regenerate energy changing the motor roll, this component is no longer consumer, all times that the driver not accelerates or brake, the bus will search the inertia, and the kinetics energy released by the movement will be converted of an electric energy through a converter integrated on the bus. In the Graph 1 you can see the relation between Energy consumption $(\mathrm{kWh})$ and the bus SOC $(\%)$, with the distance traveled $(\mathrm{km})$.

Graph 1. Energy consumption and SOC vs km

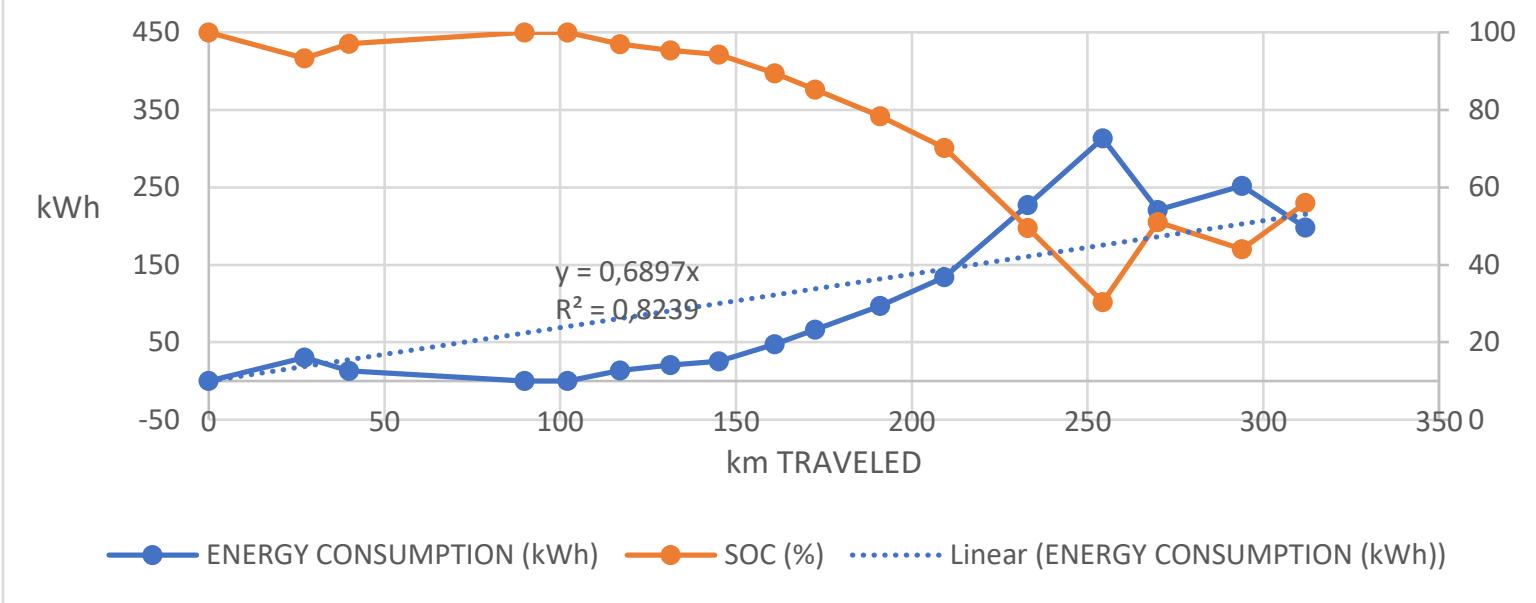

Source: made of authors

\section{DISCUSSION / PARTIAL OR FINAL RESULTS}

In the table 6 you can see the data summary with the analysis of variables: 
Table 6. Analysis of variables

\begin{tabular}{lrrrr} 
& $\begin{array}{c}\text { RELTION } \\
\mathbf{k W h} / \mathbf{k m}\end{array}$ & $\begin{array}{c}\text { CONSUMPTION } \\
\mathbf{k W h}\end{array}$ & $\begin{array}{c}\text { RELATIVE } \\
\text { ENERGY } \\
\text { COST (0,16 } \\
\text { USD/ kWh) }\end{array}$ & $\begin{array}{c}\text { RELATIVE ENERGY } \\
\text { COST (0,16 USD/ } \\
\mathbf{k W h} / \mathbf{k m}\end{array}$ \\
\hline Maximum & 1,23 & 383,76 & 61,4016 & 0,1968 \\
\hline Minimum & 0,11 & 34,32 & 5,4912 & 0,0176 \\
\hline Average & 0,63 & 196,56 & 31,4496 & 0,1008 \\
\hline Standard deviation & 0,39 & 121,68 & 19,4688 & 0,0624 \\
\hline
\end{tabular}

According with the last table, a combination of variables was made to calculate the average energy consumption costs that make up the OPEX for one unit of the operation control variable $(\mathrm{km})$, and a direct comparison was made with the consumption data of hybrid technologies and traditional diesel combustion. For the comparison exercise, the results presented by the National Laboratory of the U.S. were taken as reference. Department of Energy Office of Energy Efficiency \& Renewable Energy, in Technical Report NREL / TP-540-39742 of April 2006, King County Metro Transit Hybrid Articulated Buses: Interim Evaluation Result, study by K. Chandler and K. Walkowicz ${ }^{3}$, on this document the data was presented in cost USD / mile (0,78 USD / $\mathrm{km}$ for Diesel bus, and 0,61 USD / km for Hybrid bus), and for this exercise the equivalence is 1 mile $=1.60934 \mathrm{~km}$.

In the table 7 you can see the comparison of operating costs between traditional technologies and fully electric bus:

Table 7. Comparison of operating costs between traditional technologies and electric bus

\begin{tabular}{lc}
\multicolumn{1}{c}{ TECHNOLOGY } & $\begin{array}{c}\text { USD / km } \\
\text { ENERGY COST }\end{array}$ \\
\hline $\begin{array}{l}\text { Fully electric articulated } \\
\text { bus }\end{array}$ & 0,1008 USD \\
\hline Hybrid Articulated Bus & 0,4846 USD \\
\hline Difference & $-0,3838$ USD \\
\hline Percentage difference & $-79,19 \%$ \\
\hline Diesel articulated bus & 0,3790 USD \\
\hline Diference & $-0,2782$ USD \\
\hline Percentage diference & $-73,39 \%$ \\
\hline
\end{tabular}

Source: made of authors

\footnotetext{
${ }^{3}$ K. Chandler., K. y Walkowicz (2006). King County Metro Transit Hybrid Articulated Buses: Interim Evaluation Result. Technical Report NREL/TP-540-39742, 1 - 42.
} 
The study results carried, allowed to conclude that in articulated buses (18 m) fully electric traction technology there is a difference of $79,19 \%$ in energy consumption compared to traditional Diesel technology, and $73,39 \%$ in energy consumption in respect to hybrid technology, these are positively impacts on the OPEX; this generates new input information to feed the economic evaluation models in the fleet renewal processes of transport systems.

\section{RECOMMENDATIONS}

- It is necessary to carry out a comparative analysis between traditional and fully electrical technologies for other bus typologies different than the articulated $(18 \mathrm{~m})$, in other transport systems.

- It is necessary to develop tests of vehicles for fully electrical technologies in transport systems such as special transport systems, inter-city transport systems, distribution logistics systems, internal logistics systems in industrial processes, in order to evaluate the performance conditions and impact on the operation cost. 


\section{REFERENCES}

- Behrentz E.:Impacto del sistema de Transporte en los niveles de contaminación percibidos por los usuarios del espacio público. Dearq, n.o 4 (2009): 122-129. https://doi.org/10.18389/dearq4.2009.15

- $\quad$ Bouzada P., Martinelli G., and Cillero A.: Energy consumption and emissions associated with transportation by bus. Enertrans (2008). http://www.investigacionffe.es/documentos/enertrans/EnerTrans_Consumos_transporte_autob\%C3\%BAs.pdf. Consulted March 19th, 2020

- $\quad$ Chandler K. and Walkowicz K.: King County Metro Transit Hybrid Articulated Buses: Interim Evaluation Result (2006). Technical Report NREL/TP-540-39742. https://www.nrel.gov/docs/fy06osti/39742.pdf?gathStatIcon=true

- $\quad$ Edenhofer O., Pichs-Madruga R., Sokona Y., Farahani E., Kadner S., Seyboth K., Adler A., Baum I., Brunner S., Eickemeier P., Kriemann B., Savolainen J., Schlömer S., Stechow C., Zwickel T. and Minx J.C.: Summary for Policymakers. In: Climate Change 2014: Mitigation of Climate Change (2014). Contribution of Working Group III to the Fifth Assessment Report of the Intergovernmental Panel on Climate Change. Cambridge University Press. Cambridge. United Kingdom and New York. NY. USA. https://www.ipcc.ch/site/assets/uploads/2018/02/ipcc_wg3_ar5_summary-for-policymakers.pdf.

Consulted january 6th, 2020

- Grütter J.: Líneas base en proyectos de transporte urbano (2006). Biblioteca del Banco Interamericano de Desarrollo. http://centro.paot.org.mx/documentos/bid/lineas_base.pdf

- $\quad$ Istrate M., Nicolae V. and Vîlcan A.: The reduction of the fuel consumption and of the pollution through the city public transport, Vol. 564 (2019). IOP Conf. Series: Materials Science and Engineering 564, DOI: 10.1088 / 1757-899X / 564/1/012122. Innovative Manufacturing Engineering and Energy (IManEE 2019) - "50 Years of Higher Technical Education at the University of Pitesti" - The 23rd edition of IManEE 2019 International Conference 22-24 May 2019, University of Pitesti, Romania

- La electromovilidad en el transporte público en América Latina. Depósito legal: DC2019000315 ISBN: 978-980-422-143-9 (2019) 10-11. https://scioteca.caf.com/bitstream/handle/123456789/1466/La\%20electromovilidad\%20en\%20el\%20tra nsporte \%20publico\%20de\%20America\%20Latina.pdf?sequence $=6 \&$ isAllowed $=y$. Consulted March $23 \mathrm{dr}, 2020$.

- $\quad$ Mokate. K.: La evaluación socioeconomica de proyectos de inversión: el estado del arte (2004). Ed. Universidad de los Andes. http://www.saber.ula.ve/bitstream/handle/123456789/19346/articulo7.pdf;jsessionid=8B4B87E1E46C7 CDB537AFE7CA648119C?sequence=2. Consulted december 22nd, 2019

- $\quad$ Raheel S., Shahzad M., Ahmad N., Zamad A., Hussan S., Asif M., Rehman A., 180 Abdullah M., Shahzadi G., and Waseem M.: Performance Evaluation of Bus Rapid Transit System: A 181 Comparative Analysis of Alternative Approaches for Energy Efficient Eco-Friendly Public Transport 182 System (2020). Energies 13 (6), 1377; https://doi.org/10.3390/en13061377 
- $\quad$ Reina G., Paiano M., and Blanco J.: Vehicle parameter estimation using a model-based estimator. Mechanical Systems and Signal Processing. Vol. 87, Part B, 15 March 2017, Pages 227-241. https://doi.org/10.1016/j.ymssp.2016.06.038

- $\quad$ Rodríguez. P. \& Behrentz. E.: Elementos técnicos del plan decenal de descontaminación de Bogotá. Inventario de emisiones provenientes de fuentes fijas y móviles de la ciudad Bogotá (2009). Grupo de Estudios en Sostenibilidad Urbana y Regional (SUR). Ed. Facultad de Ingeniería Universidad de los Andes. https://uniandes.edu.co/sites/default/files/asset/document/parte-A-PDDB.pdf. Consulted January 27th, 2020

- Salon D. and Shewmake S.: Opportunities for Value Capture to Fund Public Transport: A Comprehensive Review of the Literature with a Focus on East Asia (February 1, 2011). Available at SSRN: https://ssrn.com/abstract=1753302 or http://dx.doi.org/10.2139/ssrn.1753302

- $\quad$ Zargari S. and Khan A.: Fuel Consumption Model for Bus Rapid Transit. Journal of Advanced Transportation, Vol. 37 No. 2 (2010), pp. 139 - 157. https://doi.org/10.1002/atr.5670370202

- $\quad$ Zeer, V \& Filatov, A \& Vetrov, S \& Glukhikh, Ruslan \& Perikov, D. (2019). Relevance of using electrobuses as public transport in the city of Krasnoyarsk. IOP Conference Series: Materials Science and Engineering. 632. 012005. 10.1088/1757-899X/632/1/012005. 